\title{
INTENSITAS ANCAMAN KEAMANAN SISTEM INFORMASI AKUNTANSI KOMPUTERISASIAN
}

\section{YULIUS KURNIA SUSANTO dan RATIH HANDAYANI}

\author{
Trisakti School of Management, J1. Kyai Tapa No.20 Grogol, Jakarta 11440, \\ siou_chiang@yahoo.com
}

\begin{abstract}
The objective of the paper was (1) there are significant security threats of CAIS on the organization types, (2) there is difference among the organization types regarding the security threats of CAIS, (3) there are difference between integration-on line and integration-manual CAIS regarding the security threats of CAIS. Eighty four respondents from Jakarta organizations had participated in this research. The collecting data used a questionnaire survey via electronicmail and post. Data were analyzed using a Kruskal-Wallis test. The results showed that first there is significant security threats of CAIS in Jakarta Organizations, like that the accidental entry of bad data, accidental destruction of data, employees' sharing of passwords and introduction of computer viruses the to CAIS are the significant security threats of CAIS in Jakarta Organizations. Second, there is no difference among the organization types regarding the security threats of CAIS. Third, there is no difference between integration-on line and integration-manual CAIS regarding the security threats of CAIS. But, there is difference between integration-on line and integration-manual CAIS regarding introduction of computer viruses to the CAIS.
\end{abstract}

Keywords: Security threats, information technology, computerized accounting information systems, integration.

\section{PENDAHULUAN}

Dewasa ini terjadi perubahan yang sangat drastis dalam teknologi informasi, yaitu berkembangnya sistem yang user-friendly dan keinginan perusahaan untuk memperoleh serta mengimplementasikan sistem komputer yang up-to-date dan software yang mudah digunakan. Perubahan tersebut diharapkan akan membuat tugas akuntansi menjadi lebih cepat dan akurat. Teknologi informasi mengalami perkembangan yang sangat cepat daripada tindaklanjut pengendalian dan perkembangan pengetahuan karyawan, keterampilan, kesadaran dan pemenuhan akan teknologi informasi. 
Perubahan tersebut juga menyebabkan risiko keamanan yang berkaitan dengan sistem informasi akuntansi komputerisasian (SIAK) mengalami kenaikan (Erns \& Young 1994). Seperti yang diungkapkan oleh Davis (1996), Erns \& Young (1994) menyebutkan bahwa manager kadang-kadang mengorbankan keamanan sistem untuk menerapkan teknologi baru. Pengorbanan ini berdampak pada pelaporan keuangan eksternal dan pembuatan keputusan internal. Tanpa adanya tambahan keamanan, tidak akan menjamin kualitas informasi yang disediakan oleh sistem. Hal ini dapat mendatangkan masalah karena keputusan yang diambil berasal dari data yang tidak akurat dengan kemanan yang kurang.

Di sisi lain, kemajuan teknologi informasi juga menciptakan risiko yang signifikan terkait dengan keamanan dan integritas SIAK. Sering kita mendengar dan membaca berbagai publikasi yang terkait dengan ancaman keamanan SIAK seperti kesalahan data, informasi keuangan yang salah, pelanggaran terhadap pengendalian internal, pencurian, pembongkaran, kebakaran dan sabotase. Organisasi harus peduli dengan potensi ancaman keamanan yang mungkin dapat mengganggu SIAK mereka dan mengimplementasikan pengendalian keamanan untuk mencegah, mendeteksi dan mengkoreksi pelanggaran keamanan. Meskipun berbagai upaya sedapat mungkin telah dibuat oleh para praktisi akuntansi dalam mengurangi kerentanan SIAK bagi peristiwa semacam ini, usaha peningkatan keamanan SIAK harus tetap diperlukan (Abu-Musa 2003).

Sebelumnya penelitian ini telah dilakukan oleh berbagai peneliti antara lain Loch et al. (1992) yang menyebutkan bahwa ancaman keamanan SIAK yang paling besar berasal dari dalam perusahaan. Davis (1996) menyatakan bahwa sistem microcomputer dengan hubungan network keluar merupakan lingkungan yang paling tinggi tingkat risiko ancaman keamanan SIAK daripada lingkungan mainframe yang memiliki tingkat risiko yang rendah. Seperti yang diungkapkan oleh Abu-Musa (2004), Ryan dan Bordoloi (1997) menemukan adanya perbedaan ancaman keamanan SIAK antara lingkungan client server dan lingkungan mainframe. Sedangkan Henry (1997) melakukan survai pada perusahaan di Hampton Roads, Virginia, USA, untuk menentukan asal mula SIAK dan sistem kemanan yang mereka pakai.

Abu-Musa (2006) menemukan adanya ancaman keamanan SIAK atas organisasi sektor bank di Mesir dan juga menemukan bahwa tidak ada perbedaaan di antara organisasi sektor bank dalam kaitannya dengan berbagai ancaman keamanan yang mengganggu SIAK kecuali ancaman keamanan SIAK untuk akses data dan/ atau sistem secara tidak sah oleh pihak luar (hacker). Hasil penelitian tersebut konsisten dengan Abu-Musa (2004) yang melakukan penelitian di Arab Saudi, yang menyebutkan bahwa terdapat ancaman keamanan SIAK atas berbagai tipe organiasi yang berbeda dan juga tidak menemukan perbedaan ancaman keamanan SIAK di antara tipe organisasi yang berbeda.

Berdasarkan atas uraian hasil penelitian-penelitian sebelumnya, maka peneliti tertarik untuk menganalisis berbagai ancaman keamaman SIAK atas berbagai Organiasi yang ada di Jakarta, Indonesia, mengingat Indonesia merupakan negara berkembang yang SIAK-nya sama dengan negara berkembang lainnya seperti Arab Saudi dan Mesir. 
Penelitian ini disusun dengan urutan penulisan sebagai berikut pertama, pendahuluan menjelaskan mengenai latar belakang masalah, tujuan penelitian dan organisasi penulisan. Kedua, deteksi earnings management dan hubungannya dengan relevansi nilai informasi akuntansi. Ketiga, metoda penelitian terdiri atas pemilihan sampel dan pengumpulan data, definisi operasional dan pengukuran variabel serta metoda analisis. Keempat, hasil penelitian yang berisi statistik deskriptif serta hasil dan interpretasi pengujian hipotesis. Terakhir, penutup yang berisi simpulan, keterbatasan penelitian dan saran untuk peneltian selanjutnya.

\section{RERANGKA TEORITIS DAN PENGEMBANGAN HIPOTESIS}

Ancaman keamanan sistem informasi akuntansi komputerisasian (SIAK) merupakan lingkup penelitian yang relatif baru karena masih kurangnya studi literatur mengenai penelitian ini khususnya di Indonesia. Aktivitas utama penelitian ini adalah: mendaftar ancaman keamanan yang mungkin mengganggu SIAK atas suatu organisasi; dan menemukan ancaman keamanan yang signifikan diterima. Salah satu penelitian yang paling penting dalam lingkup ini dikemukakan oleh Loch et al. (1992) yang menemukan bahwa persepsi sistem informasi manajemen (SIM) Eksekutif yang menyangkut ancaman keamanan dalam microkomputer, mainframe computer dan lingkungan network. Penelitian Loch et al. (1992) diarahkan pada dua pertanyaan yaitu apa sajakah yang mengancam sistem informasi dan data? dan manakah di antara ancaman tersebut merupakan ancaman paling serius?

Loch et al. (1992) mengembangkan daftar dua belas ancaman keamanan SIAK. Loch et al. (1992) menggunakan tiga metoda analisis data (weighted votes, the number of first place votes and unit votes) untuk mendeskripsikan keseluruhan makna dari ancaman keamanan SIAK. Hasil penelitian Loch et al. (1992) menunjukkan bahwa bencana alam dan ketidaksengajaan kesalahan karyawan terletak pada peringkat ancaman teratas yang diperoleh dari ketiga metoda. Hasil penelitian Loch et al. (1992) menyebutkan bahwa ancaman eksternal yang diterima lebih kecil daripada ancaman internal. Hasil ini memperkuat para ahli yang menyatakan bahwa ancaman terbesar berasal dari dalam perusahaan sendiri. Loch et al. (1992) juga menyatakan bahwa perusakan data secara tidak sengaja oleh karyawan, ketidaksengajaan memasukkan data yang salah oleh karyawan dan ketidakcukupan pengendalian melalui media penyimpanan sebagai ancaman yang paling penting dalam sebuah lingkungan microcomputer. Tiga ancaman yang paling penting pada mainframe computer adalah kesengajaan memasukkan data yang salah oleh karyawan, bencana alam, perusakan data secara sengaja oleh karyawan. Bencana alam, akses data/sistem oleh para hacker dan pengendalian yang lemah atau tidak efektif merupakan ancaman utama dalam lingkungan network.

Sejak keamanan SIAK menjadi salah satu perhatian utama dalam sistem informasi. Davis (1996) melakukan penelitian pada sejumlah sampel, yang secara random diambil dari anggota Information Systems Audit and Control Association (ISACA) dan American Instituted of Certified Public Accountants (AICPA). Hasil 
penelitian Davis (1996) menunjukkan bahwa sebagian besar responden merasa bahwa ada sedikit tingkat risiko keamanan SIAK. Perbedaan lingkungan perkomputeran memiliki perbedaan tingkat risiko keamanan. Hal ini konsisten dengan penelitian Davis (1996) yang menunjukkan bahwa sistem microcomputer dengan hubungan network keluar merupakan lingkungan yang paling tinggi risiko ancaman keamanan SIAK, berbeda dengan lingkungan mainframe yang memiliki tingkat risiko paling rendah.

Belakangan ini, perkomputeran client server menjadi alternatif serius dalam perkomputeran mainframe pada beberapa organisasi. Meskipun sistem perkomputeran client server menawarkan beberapa keuntungan, mereka juga menunjukkan risiko tambahan dari lingkungan perkomputeran, yaitu fleksibilitas yang membuat mereka lebih menarik serta membuat mereka juga lebih rawan terhadap ancaman keamanan SIAK. Seperti yang diungkapkan oleh Abu-Musa (2004), Ryan dan Bordoloi (1997) menemukan bagaimana perusahaan berpindah dari mainframe menuju ke lingkungan client server. Tujuan penelitiannya adalah untuk memperoleh bukti empiris: (1) adanya perbedaan ancaman keamanan SIAK antara lingkungan client server dan mainframe; (2) Adanya perbedaan tingkat persiapan yang menyangkut perlindungan terhadap ancaman keamanan SIAK pada kedua lingkungan tersebut; (3) Adanya kesesuaian antara ukuran yang digunakan untuk mempersiapkan perlindungan terhadap ancaman keamanan SIAK dengan ancaman keamanan SIAK yang diterima pada kedua lingkungan tersebut.

Hasil penelitian Ryan dan Bordoloi (1997) menunjukkan bahwa dari lima belas ancaman keamanan SIAK, tujuh diantaranya berkaitan secara signifikan dengan lingkungan perusahaan. Kelemahan penelitian Ryan dan Bordoloi (1997), seperti yang diungkapkan oleh Abu-Musa (2004), adalah tidak jelas dalam membedakan antara ancaman kemanan SIAK dan ketidakcukupan pengendalian keamanan. Mereka memperlakukan beberapa ketidakcukupan pengendalian keamanan sebagai ancaman kemanan (seperti ketidakcukupan trial audit dan ketidakcukupan atau ketiadaan prosedur logon). Ryan dan Bordoloi (1997) juga menyatakan bahwa beberapa ancaman keamanan SIAK tidak dinyatakan dalam bentuk yang tegas. Meskipun demikian, mereka berargumen bahwa banyak ukuran kekuatan yang digunakan untuk menghadapi ancaman keamanan SIAK demi kelangsungan organisasi. Oleh karena itu, penelitian ini membedakan secara jelas antara ancaman kemanan dan pengendalian.

Henry (1997) melakukan survai pada perusahaan di Hampton Roads, Virginia, USA, untuk menentukan asal mula SIAK dan sistem kemanan yang mereka pakai. Ia berusaha mengetahui derajat koresponden antara teori dan praktik sesungguhnya dengan menggunakan tujuh cara perlindungan terhadap ancaman keamanan SIAK yaitu encryption, akses password, backup data, perlindungan terhadap virus, otorisasi bagi perubahan sistem, keamanan sistem fisik dan audit secara berkala.

Penelitian Abu-Musa (2006) menguji pendapat mengenai ancaman keamanan SIAK dari kepala bagian audit internal dan kepala bagian komputer pada organisasi Perbankan. Hasil penelitian Abu-Musa (2006) menunjukkan bahwa ketidaksengajaan memasukan data yang salah oleh karyawan, kesengajaan memasukan 
data yang salah oleh karyawan, karyawan membagi-bagikan password, pengenalan virus komputer pada sistem, bencana alam dan ulah manusia, dan mencetak serta menyebarkan informasi secara langsung kepada seseorang yang tidak berhak untuk menerimanya, seluruhnya signifikan menjadi ancaman kemanan SIAK dalam organisasi Perbankan. Selain itu, Abu-Musa (2006) juga menyebutkan bahwa tidak ada perbedaaan di antara organisasi Perbankan dalam kaitannya dengan berbagai ancaman keamanan yang mengganggu SIAK kecuali ancaman keamanan SIAK untuk akses data dan/atau sistem secara tidak sah oleh pihak luar (hacker).

Hasil penelitian tersebut diperkuat oleh Abu-Musa (2004) yang melakukan penelitian di Arab Saudi, yang menyebutkan bahwa terdapat ancaman keamanan SIAK atas berbagai tipe organiasi yang berbeda. Abu-Musa (2004) juga tidak menemukan perbedaan ancaman keamanan SIAK di antara tipe organisasi yang berbeda.

Berdasarkan hasil penelitian-penelitian sebelumnya seperti yang telah diuraikan di atas, peneliti tertarik untuk melakukan penelitian tentang ancaman keamanan sistem informasi akuntansi komputerisasian atas berbagai tipe organisasi di Jakarta dengan menggunakan sembilan belas ancaman keamanan SIAK yang digunakan oleh Abu-Musa (2004). Dalam penelitian ini ditambahkan satu permasalahan yang tidak dibahas dalam penelitian Abu-Musa (2004) yaitu adakah perbedaan ancaman keamanan SIAK antara organisasi yang menggunakan SIAK yang terintegrasi dan SIAK yang terintegrasi-manual. Selain tipe organisasi dan kelompok responden, SIAK yang terintegrasi secara on-line akan lebih terbuka untuk mendapatkan ancaman keamanan SIAK daripada yang manual. Hipotesis-hipotesis yang diajukan adalah:

$\mathrm{H}_{1}$ : Terdapat ancaman keamanan yang paling mengganggu sistem informasi akuntansi komputerisasian atas berbagai tipe organisasi.

$\mathrm{H}_{2}$ : Terdapat perbedaan ancaman keamanan SIAK antar tipe organisasi yang berbeda.

$\mathrm{H}_{3}$ : Terdapat perbedaan ancaman keamanan SIAK antara organisasi yang menggunakan SIAK yang terintegrasi secara on-line dan terintegrasi secara manual.

\section{METODA PENELITIAN}

Sampel diambil secara purposive dari berbagai tipe organisasi yang memiliki SIAK (Manufaktur, Perusahaan Jasa, Perbankan, Perdagangan Ritail, Pemerintah dan Pendidikan). Purposive sampling digunakan karena informasi yang akan diambil berasal dari sumber yang sengaja dipilih berdasarkan kriteria yang telah ditetapkan peneliti (Sekaran 2003). Kriteria yang ditetapkan adalah organisasi yang paling tidak sudah menggunakan sistem informasi akuntansi komputerisasian secara terintegrasi (networking) walaupun masih ada yang manual. Subjek penelitian ini adalah manager akuntansi. Mereka paling tidak sudah bekerja pada bidangnya selama dua tahun atau lebih.

Penelitian ini menggunaan internet untuk pengumpulan data dengan jalan menyebarkan kuisioner melalui electronic-mail dan pernah dipraktikkan dalam 
penelitian Achyari (2000). Pengumpulan data juga menggunakan jasa pos. Jumlah kuisioner yang berhasil diperoleh sebanyak sembilan puluh empat kuisioner dan yang memenuhi kriteria penelitian sebanyak delapan puluh tiga kuisioner. Penggunaan $e$-mail dapat dijadikan sebagai tanda bahwa organisasi telah menggunakan sistem informasi akuntansi komputerisasian yang terintegrasi. Untuk memastikannya dalam kuisioner ditanyakan apakah organisasi sudah menggunakan sistem informasi akuntansi komputerisasian yang terintegrasi.

Secara umum ada empat jenis ancaman keamanan SIAK yang dihadapi oleh perusahaan yaitu: kehancuran karena bencana alam dan politik, kesalahan pada software dan tidak berfungsinya peralatan, tindakan yang tidak disengaja, dan tindakan yang disengaja (Romney dan Steinbart 2003). Penelitian ini menggunakan sembilan belas item ancaman keamanan sistem informasi akuntansi komputerisasian (SIAK) yang pernah digunakan oleh Abu-Musa (2004).

Pengukuran kesembilan belas ancaman keamanan SIAK tersebut menggunakan lima skala untuk mengukur intensitas ancaman keamanan SIAK yaitu setiap tahun atau tidak pernah, setiap bulan, setiap minggu, setiap hari dan lebih dari sekali dalam sehari atau lebih sering. Responden diminta untuk memberi skala intensitas setiap ancaman keamanan SIAK atas organisasi mereka.

\section{HASIL PENELITIAN}

Demografi responden dapat dilihat pada Tabel 1 sebagai berikut:

Tabel 1 Demografi Responden

\begin{tabular}{|c|c|c|}
\hline Kriteria & Jumlah & Prosentase \\
\hline \multicolumn{3}{|l|}{ Sektor Industri } \\
\hline$\square$ Manufaktur & 23 & $27,7 \%$ \\
\hline$\square$ Perusahaan Jasa & 19 & $22,9 \%$ \\
\hline$\square$ Perbankan & 11 & $13,3 \%$ \\
\hline 哃 Perdagangan Ritail & 10 & $12 \%$ \\
\hline Pemerintah & 10 & $12 \%$ \\
\hline Pendidikan & 10 & $12 \%$ \\
\hline \multicolumn{3}{|l|}{ Jumlah Akuntan } \\
\hline 四 $\quad 1-5$ & 56 & $67,5 \%$ \\
\hline 6-10 & 12 & $14,5 \%$ \\
\hline 回 $11-15$ & 6 & $7,2 \%$ \\
\hline 16-20 & 9 & $10,8 \%$ \\
\hline \multicolumn{3}{|l|}{ Jumlah Ahli Sistem Informasi } \\
\hline$\square \quad 1-5$ & 65 & $78,3 \%$ \\
\hline 6-10 & 13 & $15,7 \%$ \\
\hline$\square \quad 11-15$ & 2 & $2,4 \%$ \\
\hline 品 $16-20$ & 3 & $3,6 \%$ \\
\hline
\end{tabular}




\section{Aktivitas Penyebab Kerugian Keuangan}

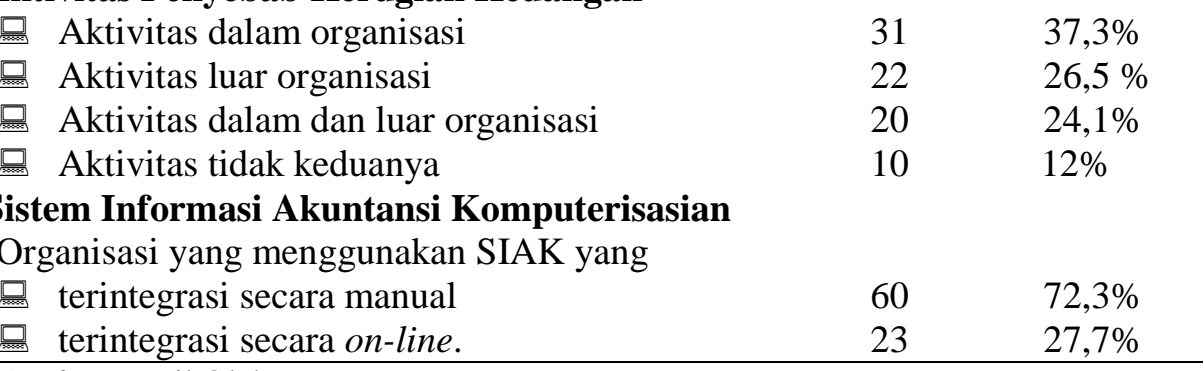

Sumber: Hasil Olah Data

Berdasarkan Tabel 1 dapat dilihat bahwa industri yang paling banyak adalah industri manufaktur sebesar $27,7 \%$ dengan jumlah akuntan dan ahli sistem informasi sebanyak 1 sampai 5 orang sebesar 67,5\% dan 78,3\%. Kerugian keuangan potensial akibat ancaman keamanan sistem informasi akuntansi komputerisasian (SIAK) adalah berasal dari aktivitas dalam perusahaan seperti tindakan karyawan sebesar 37,3\% dan sistem informasi akuntansi yang paling banyak digunakan oleh perusahaan adalah terintegrasi secara manual sebesar $72,3 \%$.

Sampel yang diperoleh berasal dari berbagai organisasi yang berbeda (lihat Gambar 1), aktivitas penyebab kerugian keuangan (lihat Gambar 2) dan organisasi yang menggunakan SIAK yang terintegrasi secara on-line dan terintegrasi secara manual (lihat Gambar 3).

Pengujian hipotesis satu ditunjukkan dengan intensitas ancaman keamanan (lihat Tabel 2). Semakin sering ancaman keamanan terjadi maka ancaman tersebut mengganggu SIAK (Abu-Musa 2004, 2006). Dalam penelitian ini intensitas ancaman keamanan yang mengganggu SIAK adalah setiap hari. Dengan asumsi apabila ancaman keamanan tersebut terjadi setiap hari maka akan mengganggu SIAK. Berdasarkan Tabel 2, ancaman keamanan yang mengganggu SIAK adalah ketidaksengajaan memasukan data yang salah oleh karyawan, perusakan data secara tidak sengaja oleh karyawan, karyawan membagi-bagikan password dan pengenalan (masuknya) virus komputer pada sistem.

Ancaman keamanan yang mengganggu SIAK untuk industri Manufaktur adalah ketidaksengajaan memasukan data yang salah oleh karyawan; Untuk industri Jasa adalah ketidaksengajaan memasukan data yang salah oleh karyawan, perusakan data secara tidak sengaja oleh karyawan dan pengenalan (masuknya) virus komputer pada sistem; Untuk industri Perbankan adalah ketidaksengajaan memasukan data yang salah oleh karyawan, perusakan data secara tidak sengaja oleh karyawan, karyawan membagi-bagikan password dan pengenalan (masuknya) virus komputer pada sistem; Untuk industri Perdagangan Ritail adalah karyawan membagibagikan password dan pengenalan (masuknya) virus komputer pada sistem; Untuk Pemerintah adalah ketidaksengajaan memasukan data yang salah oleh karyawan, perusakan data secara tidak sengaja oleh karyawan dan pengenalan (masuknya) virus komputer pada sistem; Unutuk industri Pendidikan adalah pengenalan (masuknya) virus komputer pada sistem. 


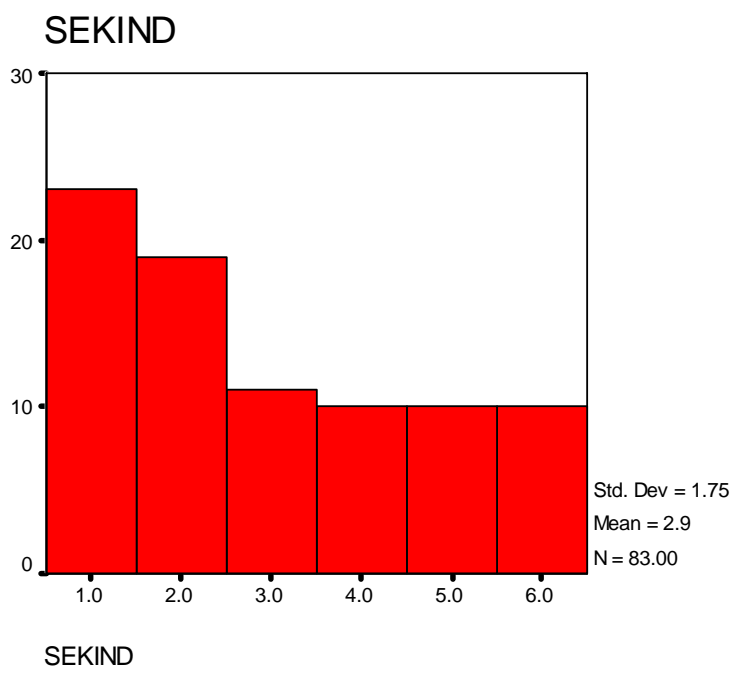

Keterangan: 1 Manufaktur, 2 Perusahaan Jasa, 3 Perbankan, 4 Perdagangan ritail, 5 Pemerintah dan 6 Pendidikan.

\section{Gambar 1 Tipe Organisasi}

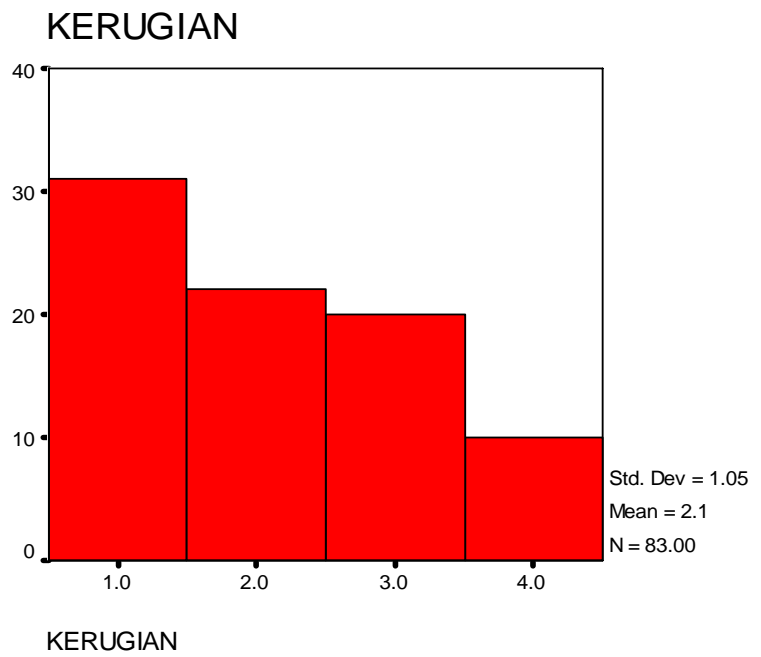

Keterangan: 1 Kerugian keuangan berasal dari aktivitas dalam organisasi, 2 Kerugian keuangan berasal dari aktivitas luar organisasi, 3 Kerugian keuangan berasal dari aktivitas dalam dan luar organisasi, 4 Kerugian keuangan berasal dari aktivitas tidak keduanya.

Gambar 2 Aktivitas Penyebab Kerugian Keuangan 


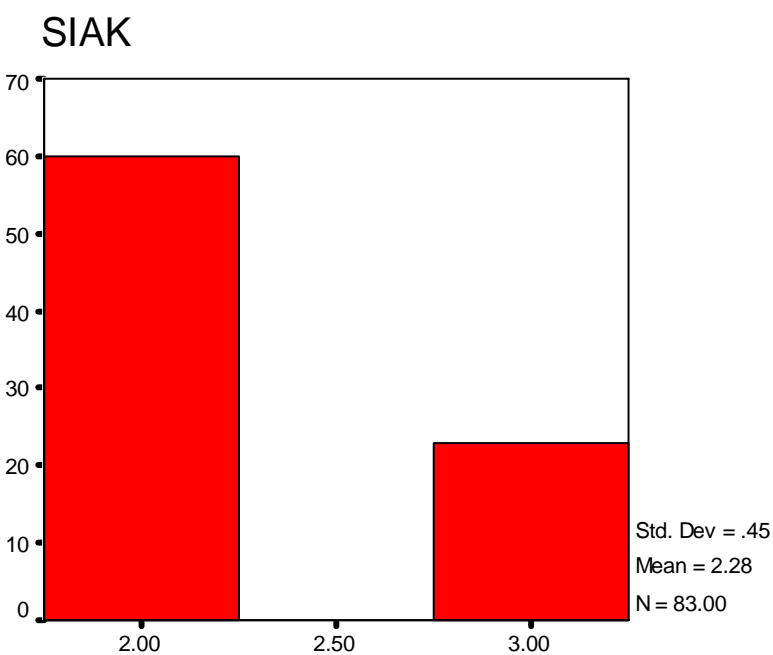

SIAK

Keterangan: 2 Organisasi yang menggunakan SIAK yang terintegrasi secara manual dan 3 terintegrasi secara on-line.

Gambar 3 Sistem Informasi Akuntansi Komputerisasian 
Tabel 2 Intensitas Ancaman Keamanan SIAK

\begin{tabular}{|c|c|c|c|c|c|c|c|c|c|c|c|}
\hline & \multirow[t]{2}{*}{ Ancaman Keamanan Sistem Informasi Akuntansi Komputerisasian } & \multicolumn{2}{|c|}{$\begin{array}{c}\text { Setiap } \\
\text { tahun atau } \\
\text { tidak pernah }\end{array}$} & \multicolumn{2}{|c|}{ Setiap bulan } & \multicolumn{2}{|c|}{$\begin{array}{l}\text { Setiap } \\
\text { minggu }\end{array}$} & \multicolumn{2}{|c|}{$\begin{array}{l}\text { Setiap } \\
\text { hari }\end{array}$} & \multicolumn{2}{|c|}{$\begin{array}{l}\text { lebih } \\
\text { sering }\end{array}$} \\
\hline & & $\mathrm{n}$ & $\%$ & $\mathrm{n}$ & $\%$ & $\mathrm{n}$ & $\%$ & $\mathrm{n}$ & $\%$ & $\mathrm{n}$ & $\%$ \\
\hline 1. & Ketidaksengajaan memasukan data yang salah oleh karyawan & 23 & 27,7 & 34 & 41 & 19 & 22,9 & 4 & 4,8 & 3 & 3,6 \\
\hline 2. & Kesengajaan memasukan data yang salah oleh karyawan & 75 & 90,4 & 6 & 7,2 & 2 & 2,4 & 0 & 0 & 0 & 0 \\
\hline 3. & Perusakan data secara tidak sengaja oleh karyawan & 49 & 59 & 24 & 28,9 & 7 & 8,4 & 0 & 0 & 3 & 3,6 \\
\hline 4. & Perusakan data secara sengaja oleh karyawan & 81 & 97,6 & 2 & 2,4 & 0 & 0 & 0 & 0 & 0 & 0 \\
\hline 5. & Akses data dan/atau sistem secara tidak sah oleh karyawan & 70 & 84,3 & 11 & 13,3 & 2 & 2,4 & 0 & 0 & 0 & 0 \\
\hline 6. & Akses data dan/atau sistem secara tidak sah oleh pihak luar (hacker) & 79 & 95,2 & 4 & 4,8 & 0 & 0 & 0 & 0 & 0 & 0 \\
\hline 7. & Karyawan membagi-bagikan password & 67 & 80,7 & 10 & 12 & 2 & 2,4 & 4 & 4,8 & 0 & 0 \\
\hline 8. & Bencana alam seperti kebakaran, banjir dan gempa bumi & 60 & 72,3 & 22 & 26,5 & 1 & 1,2 & 0 & 0 & 0 & 0 \\
\hline 9. & Bencana ulah manusia seperti kebakaran, teroris dan listrik padam & 61 & 73,5 & 19 & 22,9 & 3 & 3,6 & 0 & 0 & 0 & 0 \\
\hline & Pengenalan (masuknya) virus komputer pada sistem & 35 & 42,2 & 36 & 43,4 & 5 & 6 & 1 & 1,2 & 6 & 7,2 \\
\hline & Perusakan output & 65 & 78,3 & 17 & 20,5 & 1 & 1,2 & 0 & 0 & 0 & 0 \\
\hline & Pembuatan output yang salah & 59 & 71,1 & 22 & 26,5 & 2 & 2,4 & 0 & 0 & 0 & 0 \\
\hline & Pencurian data/informasi & 79 & 95,2 & 4 & 4,8 & 0 & 0 & 0 & 0 & 0 & 0 \\
\hline 14. & Penyalinan output secara tidak sah & 78 & 94 & 4 & 4,8 & 1 & 1,2 & 0 & 0 & 0 & 0 \\
\hline 15. & Penampilan dokumen pada monitor atau hasil cetakan yang bukan wewenangnya & 70 & 84,3 & 13 & 15,7 & 0 & 0 & 0 & 0 & 0 & 0 \\
\hline & Pencetakan dan penyebaran informasi oleh seseorang yang tidak berwenang & 77 & 92,8 & 6 & 7,2 & 0 & 0 & 0 & 0 & 0 & 0 \\
\hline & $\begin{array}{l}\text { Mencetak dan menyebarkan informasi secara langsung kepada orang yang tidak } \\
\text { berhak untuk menerimanya }\end{array}$ & 72 & 86,7 & 10 & 12 & 1 & 1,2 & 0 & 0 & 0 & 0 \\
\hline 18. & $\begin{array}{l}\text { Pemusnahan (shredding) dokumen yang diserahkan kepada seseorang yang tidak } \\
\text { jelas keamanannya }\end{array}$ & 77 & 92,8 & 4 & 4,8 & 2 & 2,4 & 0 & 0 & 0 & 0 \\
\hline 19. & Penahanan transmisi data dari lokasi yang berbeda & 75 & 90,4 & 6 & 7,2 & 2 & 2,4 & 0 & 0 & 0 & 0 \\
\hline
\end{tabular}
Sumber: Hasil Olah Data 
Hasil ini mendukung penelitan Abu-Musa (2004 dan 2006) yang menyebutkan bahwa ketidaksengajaan dan kesengajaan memasukan data yang salah oleh karyawan, ketidaksengajaan perusakan data oleh karyawan, karyawan membagibagikan password, becana alam maupun ulah manusia, pengenalan virus komputer pada sistem, perusakan output, penampilan dokumen pada monitor atau hasil cetakan yang bukan wewenangnya, pencetakan langsung dan distribusi informasi kepada orang yang tidak berhak untuk menerimanya adalah ancaman keamanan yang mengganggu SIAK di organisasi Arab Saudi.

Berdasarkan Tabel 3, hasil pengujian hipotesis dua menunjukkan bahwa tidak ada perbedaan ancaman keamanan SIAK antar tipe organisasi yang berbeda sehingga hipotesis dua tidak terdukung. Hasil pengujian hipotesis dua mengindikasikan bahwa hampir semua tipe organisasi di Jakarta mengalami ancaman keamanan SIAK yang sama. Hasil temuan ini mendukung penelitian Abu-Musa (2004, 2006) yang menyebutkan tidak ada perbedaan antar tipe organisasi yang berbeda dalam kaitannya dengan intensitas ancaman keamanan SIAK pada organisasi di Arab Saudi dan Mesir.

\section{Tabel 3}

\section{Hasil Kruskal-Wallis Test untuk Tipe Organisasi}

\begin{tabular}{|c|c|c|c|c|}
\hline & $\begin{array}{c}\text { Ancaman Keamanan Sistem Informasi Akuntansi } \\
\text { Komputerisasian }\end{array}$ & $\begin{array}{l}\text { Chi- } \\
\text { Square }\end{array}$ & $d f$ & $\begin{array}{l}\text { Asymp. } \\
\text { Sig. }\end{array}$ \\
\hline 1. & Ketidaksengajaan memasukan data yang salah oleh karyawan & 2,807 & 5 & 0,730 \\
\hline 2. & Kesengajaan memasukan data yang salah oleh karyawan & 3,147 & 5 & 0,677 \\
\hline 3. & Perusakan data secara tidak sengaja oleh karyawan & 5,317 & 5 & 0,378 \\
\hline 4. & Perusakan data secara sengaja oleh karyawan & 4,003 & 5 & 0,549 \\
\hline 5. & Akses data dan/atau sistem secara tidak sah oleh karyawan & 1,100 & 5 & 0,954 \\
\hline 6. & $\begin{array}{l}\text { Akses data dan/atau sistem secara tidak sah oleh pihak luar } \\
\text { (hacker) }\end{array}$ & 2,030 & 5 & 0,845 \\
\hline 7. & Karyawan membagi-bagikan password & 5,352 & 5 & 0,374 \\
\hline 8. & Bencana alam seperti kebakaran, banjir dan gempa bumi & 3,550 & 5 & 0,616 \\
\hline 9. & $\begin{array}{l}\text { Bencana ulah manusia seperti kebakaran, teroris dan listrik } \\
\text { padam }\end{array}$ & 6,574 & 5 & 0,254 \\
\hline 10. & Pengenalan (masuknya) virus komputer pada sistem & 1,502 & 5 & 0,913 \\
\hline 11. & Perusakan output & 3,828 & 5 & 0,574 \\
\hline 12. & Pembuatan output yang salah & 8,425 & 5 & 0,134 \\
\hline 13. & Pencurian data/informasi & 7,751 & 5 & 0,171 \\
\hline 14. & Penyalinan output secara tidak sah & 1,704 & 5 & 0,888 \\
\hline 15. & $\begin{array}{l}\text { Penampilan dokumen pada monitor atau hasil cetakan yang } \\
\text { bukan wewenangnya }\end{array}$ & 2,463 & 5 & 0,782 \\
\hline 16. & $\begin{array}{l}\text { Pencetakan dan penyebaran informasi oleh seseorang yang } \\
\text { tidak berwenang }\end{array}$ & 5,015 & 5 & 0,414 \\
\hline & $\begin{array}{l}\text { Mencetak dan menyebarkan informasi secara langsung } \\
\text { kepada orang yang tidak berhak untuk menerimanya }\end{array}$ & 0,986 & 5 & 0,964 \\
\hline & $\begin{array}{l}\text { Pemusnahan (shredding) dokumen yang diserahkan kepada } \\
\text { seseorang yang tidak jelas keamanannya }\end{array}$ & 3,172 & 5 & 0,673 \\
\hline 19. & Penahanan transmisi data dari lokasi yang berbeda & 2,119 & 5 & 0,832 \\
\hline
\end{tabular}

Sumber: Hasil Olah Data 
Tabel 4 memberikan bukti empiris bahwa secara keseluruhan tidak ada perbedaan antara organisasi yang menggunakan SIAK yang terintegrasi secara online dan terintegrasi secara manual. Akan tetapi pengenalan (masuknya) virus komputer pada sistem (Asymp.Sig.=0,013) merupakan ancaman keamanan SIAK yang berbeda antara organisasi yang menggunakan SIAK yang terintegrasi secara on-line dan terintegrasi secara manual. Ancaman pengenalan (masuknya) virus komputer pada sistem sering terjadi pada organisasi yang SIAK terintegrasi secara on-line daripada terintegrasi secara manual (lihat Tabel 5 pada AK10). Hal ini menunjukkan bahwa SIAK yang terintegrasi secara on-line sangat rentan untuk masuknya virus komputer pada sistem.

\section{Tabel 4}

Hasil Kruskal-Wallis Test untuk SIAK yang terintegrasi secara on-line dan terintegrasi secara manual

\section{Ancaman Keamanan Sistem Informasi Akuntansi Komputerisasian}

$\begin{array}{ccc}\text { Chi- } & \text { Asymp. } \\ \text { Square } & \text { Sig. }\end{array}$

1. Ketidaksengajaan memasukan data yang salah oleh karyawan

$\begin{array}{lll}1,051 & 1 & 0,305\end{array}$

2. Kesengajaan memasukan data yang salah oleh karyawan

$\begin{array}{lll}1,049 & 1 & 0,306\end{array}$

3. Perusakan data secara tidak sengaja oleh karyawan

$\begin{array}{lll}0,000 & 1 & 0,991\end{array}$

4. Perusakan data secara sengaja oleh karyawan

$\begin{array}{lll}0,776 & 1 & 0,378\end{array}$

5. Akses data dan/atau sistem secara tidak sah oleh karyawan

$\begin{array}{lll}0,120 & 1 & 0,729\end{array}$

6. Akses data dan/atau sistem secara tidak sah oleh pihak luar $\begin{array}{lll}1,030 & 1 & 0,310\end{array}$ (hacker)

7. Karyawan membagi-bagikan password

$\begin{array}{lll}1,14 & 1 & 0,314\end{array}$

8. Bencana alam seperti kebakaran, banjir dan gempa bumi

$\begin{array}{lll}0,059 & 1 & 0,809\end{array}$

9. Bencana ulah manusia seperti kebakaran, teroris dan listrik padam

10. Pengenalan (masuknya) virus komputer pada sistem

11. Perusakan output

$3,098 \quad 1 \quad 0,078$

12. Pembuatan output yang salah

13. Pencurian data/informasi

$6,162 \quad 1 \quad 0,013^{*}$

$\begin{array}{lll}0,308 & 1 & 0,579\end{array}$

$\begin{array}{lll}0,181 & 1 & 0,670\end{array}$

14. Penyalinan output secara tidak sah

$\begin{array}{lll}0,015 & 1 & 0,902\end{array}$

15. Penampilan dokumen pada monitor atau hasil cetakan yang

$\begin{array}{lll}0,366 & 1 & 0,545\end{array}$ bukan wewenangnya

16. Pencetakan dan penyebaran informasi oleh seseorang yang

$\begin{array}{lll}0,879 & 1 & 0,349\end{array}$ tidak berwenang

17. Mencetak dan menyebarkan informasi secara langsung kepada orang yang tidak berhak untuk menerimanya

18. Pemusnahan (shredding) dokumen yang diserahkan kepada seseorang yang tidak jelas keamanannya

19. Penahanan transmisi data dari lokasi yang berbeda

$*=$ sig. $<0,05$

Sumber: Hasil Olah Data 


\section{Tabel 5}

Mean Rank untuk SIAK yang terintegrasi secara on-line dan terintegrasi secara manual

\begin{tabular}{lllllllllll}
\hline & AK1 & AK2 & AK3 & AK4 & AK5 & AK6 & AK7 & AK8 & AK9 & AK10 \\
\hline $\begin{array}{l}\text { On-line } \\
\text { (n=23) }\end{array}$ & 46,15 & 39,76 & 41,96 & 41,00 & 41,07 & 43,61 & 44,96 & 41,20 & 36,2 & 51,74 \\
$\begin{array}{l}\text { Manual } \\
\text { (n=60) }\end{array}$ & 40,41 & 42,86 & 42,02 & 42,38 & 42,36 & 41,38 & 40,87 & 42,31 & 44,22 & 38,27 \\
\hline
\end{tabular}

Sumber: Hasil Olah SPSS

\begin{tabular}{llllllllll}
\hline & AK11 & AK12 & AK13 & AK14 & AK15 & AK16 & AK17 & AK18 & AK19 \\
\hline $\begin{array}{l}\text { On-line } \\
\text { (n=23) }\end{array}$ & 43,0 & 40,57 & 41,80 & 43,07 & 44,52 & 44,41 & 41,85 & 44,8 & 43,28 \\
$\begin{array}{l}\text { Manual } \\
\text { (n=60) }\end{array}$ & 41,35 & 42,55 & 42,08 & 41,59 & 41,03 & 41,08 & 42,06 & 41,13 & 41,51 \\
\hline
\end{tabular}

Sumber: Hasil Olah Data

\section{PENUTUP}

Tujuan utama dari penelitian ini adalah untuk menyelidiki ancaman keamanan yang signifikan diterima oleh sistem informasi akuntansi komputerisasian (SIAK), melalui intensitas keterjadian mereka dalam berbagai organisasi di Jakarta. Daftar ancaman keamanan SIAK yang digunakan telah dikembangkan berdasarkan penelitian sebelumnya (sebagai contoh, Loch et al.1992, Davis 1996, Henry 1997, Abu-Musa 2004, 2006).

Hasil penelitian memberikan tiga bukti empiris, yaitu pertama, terdapat ancaman keamanan yang mengganggu SIAK adalah ketidaksengajaan memasukan data yang salah oleh karyawan, perusakan data secara tidak sengaja oleh karyawan, karyawan membagi-bagikan password dan pengenalan (masuknya) virus komputer pada sistem. Kedua, tidak ada perbedaan ancaman keamanan SIAK antar tipe organisasi yang berbeda.

Terakhir, secara keseluruhan tidak ada perbedaan antara organisasi yang menggunakan SIAK yang terintegrasi secara on-line dan terintegrasi secara manual. Akan tetapi pengenalan (masuknya) virus komputer pada sistem merupakan ancaman keamanan SIAK yang berbeda antara organisasi yang menggunakan SIAK yang terintegrasi secara on-line dan terintegrasi secara manual. Ancaman pengenalan (masuknya) virus komputer pada sistem sering terjadi pada organisasi yang SIAK terintegrasi secara on-line daripada terintegrasi secara manual.

Implikasi penelitian ini adalah bahwa pengelola organisasi akan lebih memperhatikan ancaman-ancaman keamanan yang terkait dengan sistem informasi akuntansi komputerisasian (SIAK) terlebih pada ancaman pengenalan (masuknya) virus komputer pada sistem. Pengelola Oganisasi perlu meng-update software antivirus terlebih pada virus yang merusak jejaring SIAK. Bagi karyawan yang pekerjaannya terkait dengan SIAK akan lebih berusaha untuk mengatasi berbagai ancaman keamanan yang mengganggu jalannya kegiatan SIAK, seperti tidak cerobah dalam mengelola data dan/atau sistem. 
Keterbatasan penelitian ini adalah jumlah sampel untuk tiap tipe organisasi yang kurang proposional serta sedikitnya sampel yang diperoleh. Hal ini disebabkan oleh kuisioner yang dikirimkan banyak tidak direspon, mengingat responden yang digunakan, yaitu manajer akuntansi. Untuk penelitian selanjutnya sebaiknya menggunakan responden karyawan akuntansi dan keuangan yang terlibat langsung dengan SIAK. Keterbatasan lainnya adalah daftar ancaman keamanan SIAK yang digunakan adalah sembilan belas butir. Menurut responden masih ada ancaman keamanan SIAK lainnya yang terjadi di perusahaan mereka tetapi tidak teridentifikasi dalam penelitian ini, seperti ketidakjujuran karyawan, kesalahan data inputan dari nasabah, kesalahpahaman penyampaian informasi dan kelupaan backup data. Untuk penelitian selanjutnya mempertimbangkan ancaman keamanan tersebut.

Hasil penelitian ini tidak dapat digeneralisasi untuk semua industri di Jakarta. Bagaimanapun, penelitian lebih lanjut perlu dilakukan dengan menambah jumlah sampel untuk memperluas dan mengembangkan penelitian ini. Penelitian yang lebih jauh dibutuhkan untuk menunjukkan bukti empiris dari daerah lainnya seperti Medan, Semarang dan Surabaya yang notabene-nya daerah tersebut merupakan salah satu pusat bisnis di Indonesia. Studi komparatif dapat diambil untuk menyelidiki perbedaan yang signifikan antara daerah satu dan daerah lainnya dalam kaitannya dengan penelitian isu keamanan SIAK.

\section{REFERENSI:}

Achyari, Didi. 2000. Pemanfaatan Internet untuk Riset dan Implikasi terhadap Riset Akuntansi. Jurnal Ekonomi dan Bisnis Indonesia 15 (2), hlm. 257-267.

Abu-Musa, Ahmad A. 2003. The Perceived Threats to the Security of Computerized Accounting Information Systems. The Journal of American Academy of Business Vol.3, No.1, September, hlm. 9-20.

Abu-Musa, Ahmad A. 2004. Exploring the Perceived Threats of Computerized Accounting Information Systems in Emerging Countries: an Emprical Study on Saudi Organizations. European Accounting Information Systems Conference 2004. Prague: Annual Congress of the European Accounting Association.

Abu-Musa, Ahmad A. 2006. Perceived Security Threats of Computerized Accounting Information Systems in the Egyptian Banking Industry. Journal of Information Systems Vol.20, No.1 Spring, hlm. 187-203.

Davis, Charles E. 1996. Perceived Security Threats to today's Accounting Information Systems: a Survey of CISAs. IS Audit \& Control Journal Vol.3, hlm. 38-41.

Febrian, Jack dan Farida Andayani 2002. Kamus Komputer dan Istilah Teknologi Informasi. Bandung: Penerbit Informatika Bandung.

Hair, J.F., Anderson, R.E., dan Black, W.C. 2006. Multivariate Data Analysis. Sixth Edition. New Jersy: Prentice Hall International, Inc.

Henry, Laurie 1997. A Study of the Nature and Security of Accounting Information Systems: The Case of Hampton Roads, Virginia. The Mind-Atlantic of Business. Vol.33, Iss.69, hlm. 171189.

Loch, Karen D., Houstan H. Carr dan Merrill E. Warkentin 1992. Threats to Information Systems: Today's Reality, Yesterday's Understanding. MIS Quarterly, Juni, hlm. 173-186.

Romney, B. Marshall dan Paul J. Steinbart. 2003. Accounting Information Systems. New Jersey: Pearson Education, Inc.

Sekaran, Uma. 2003. Research Methods for Business: A Skill-Building Approach. Fourth Edition. New York: John Wiley \& Sons, Inc. 